\title{
Expression of mRNA Mastermind-like Domain-containing 1, Androgen Receptor, and Estrogen Receptor in Patients with Hypospadias
}

Prahara Yuri ${ }^{1 *}$, Didik Setyo Heriyanto ${ }^{2}$, Arry Rodjani ${ }^{3}$, Yonas Immanuel Hutasoit ${ }^{4}$, Andre Yudha Alfanius Hutahaean ${ }^{5}$, Muhammad Ridhaniar Rahman ${ }^{1}$, Reisya Rizki Amanda ${ }^{6}$, Yusuf Kirana Raksawardana ${ }^{6}$, Rahmadani Puji Lestari ${ }^{1}$, Firly Putri Fardilla ${ }^{1}$, Irfan Wahyudi ${ }^{3}$

${ }^{1}$ Division of Urology, Department of Surgery, Faculty of Medicine, Public Health and Nursing, Universitas Gadjah Mada, Dr. Sardjito Hospital, Yogyakarta, Indonesia; ${ }^{2}$ Department of Anatomical Pathology, Faculty of Medicine, Public Health and Nursing, Universitas Gadjah Mada, Dr.Sardjito Hospital, Yogyakarta, Indonesia; ${ }^{3}$ Department of Urology, Faculty of Medicine, Universitas Indonesia, Cipto Mangunkusumo Hospital, Jakarta, Indonesia; ${ }^{4}$ Division of Urology, Department of Surgery, Faculty of Medicine, Fatmawati Hospital, Jakarta, Indonesia; ${ }^{5}$ Division of Urology, Department of Surgery, Harapan Kita Mother and Children Hospital, Jakarta, Indonesia; ${ }^{6}$ Medical Student, Faculty of Medicine, Public Health and Nursing, Universitas Gadjah Mada, Dr. Sardjito Hospital, Yogyakarta, Indonesia

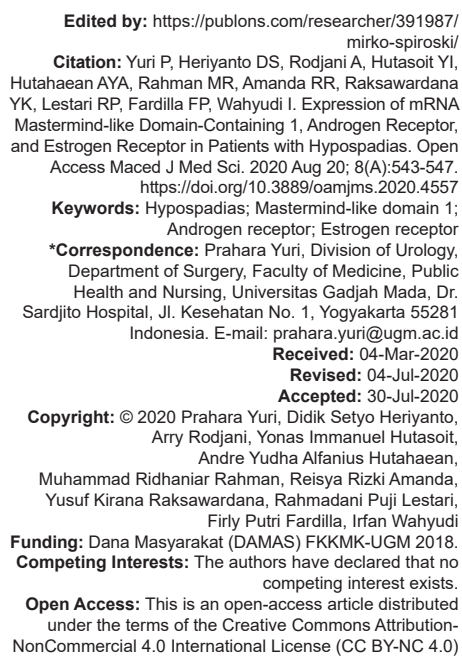

\section{Introduction}

Hypospadias is a relatively common genital anomaly in humans in which the urethral opening is not correctly positioned at the tip of the penis. Its prevalence in many countries ranges from 4 to 43 cases per 10,000 births [1]. This congenital disorder is the second most common in boys after cryptorchidism and the most frequent malformation of the penis [2]. Hypospadias is defined as a malformation of the penis due to incomplete development of the male urethra leading to the localization of the urinary meatus on the ventral side of the penis in a

\begin{abstract}
BACKGROUND: Androgen (AR) and Estrogen (ER) hormones play an important role in the prenatal and postnata development of the urogenital tract and especially the penis. Growth factors also influence the development of genital structures. Little is known about the exact role of Mastermind Like Domain 1 (MAMLD1) in sexual development. A primarily because of compromised testosterone production around the critical period for fetal sex development, but with the incidence of hypospadias.

OBJECTIVE: The objective of this study was to investigate the correlation between gene factor MAMLD1, AR, ER1 and ER2 with the incidence of hypospadias.

METHODS: From 2017-2018, peri-urethral dartos were harvested from 46 patients with proximal hypospadias, 24 patients with distal hypospadias and 10 patients with normal penile were used as controls. The expressions of MAMLD1, AR, ER1, and ER2 were investigated by one-step quantitative polymerase chain reaction.

Median age was 5 years old in the 70 patients with hypospadias and 6 years old in the control subjects. Total specimens taken included 24 distal penile, 46 proximal penile, and 10 normal penile specimens. We found decreasing MAMLD1 and AR expressions, but ER2 expression increased in patients with hypospadias compared to
\end{abstract} patients with hypospadias $(r=0.062 ; p=0.038)$

SIONS: Decreasing of MAMLD1 and AR expression was followed by increasing ER2 expression in patients with hypospadias. MAMLD1 had a positive correlation with AR so the defect of MAMLD1 may influence AR and increase the incidence of hypospadias. variable position from the glans to the perineum [3], [4]. The precise etiology remains unclear in most disorder of sexual development (DSD) cases including hypospadias. Several candidate genes and their response to environmental agents have been analyzed both in human and mouse tissues, opening many promising areas of research concerning the etiology of hypospadias [5].

Mastermind-like domain-containing 1 (MAMLD1, previously known as CXORF6) is an X-linked transcriptional coactivator [6]. It is expressed in Sertoli and Leydig cells of fetal mice around the critical period for sexual development [7]. MAMLD1 is known to be implicated in various human DSDs, including 
hypospadias. MAMLD appears to regulate testosterone production around the critical period for sex development [8]. However, the underlying mechanism of hypospadias' pathogenesis due to MAMLD1 is poorly understood.

Several genes may affect the anomalies of male development such as androgen receptors (AR) and estrogen receptors (ER). The previous studies report that several mutations specifically affect $A R$ synthesis in the testis which can lead to hypospadias. Several studies reported hemizygous mutations (as $A R$ is X-linked) in patients with hypospadias [9]. ER dysfunction may also contribute to the pathogenesis of hypospadias. Various homozygous mutations have been reported to cause hypospadias and cryptorchidism in the $46 \mathrm{XY}$ sibling [10]. As previously reported, there are two ER receptors, ER1 and ER2, which interact to form homo-heterodimer ER complexes. ER bound by ER translocates to the nucleus to activate ER-responsive genes. ER1 and ER2 are expressed in most cells of the male urethra [11]. This study examined the interaction between MAMLD1, AR, ER1, and ER2 in the development of hypospadias. We compared the expression levels of MAMLD1, AR, ER1, and ER2 between normal boys and those with hypospadias.

The objective of this study was to investigate the correlation between gene factor MAMLD1, AR, ER1, and ER2 with the incidence of hypospadias.

\section{Methods}

\section{Patients}

Seventy patients underwent repair of hypospadias without DSD and 10 normal patients who underwent circumcision as controls in four pediatric urology centers from 2017 to 2018. We divided the samples into distal hypospadias, proximal hypospadias, and controls. We used periurethral dartos obtained during chordee excision following the standard procedure using samples from RNAlater fixation. The surgical approach of each patient was decided depending on the patient's condition with distal hypospadias treated by tubularized incision plate, or Mathieu onlay island flap urethroplasty, and proximal hypospadias using Duckett, two-stage urethroplasty.

\section{Polymerase chain reaction (PCR) analysis}

All foreskin tissues of the patients were pooled in a single tube. Total RNA was extracted from a homogenized sample using the Hybrid- $R^{T M}$ Isolation Kit and cDNA was synthesized from $200 \mathrm{ng}$ of total RNA using NEXpro ${ }^{\mathrm{TM}}$ quantitative reverse transcription (qRT)-PCR kit. Quantitative PCR was performed for MAMLD1, AR, ER1, and ER2. We used GAPDH as internal control, Table 1.
Amplification conditions consisted of an initial denaturation step at $95^{\circ} \mathrm{C}$ for $10 \mathrm{~min}$, followed by 40 cycles at $95^{\circ} \mathrm{C}$ for $20 \mathrm{~s}$, at $56^{\circ} \mathrm{C}$ for $40 \mathrm{~s}$, and at $72^{\circ} \mathrm{C}$ for $60 \mathrm{~s}$. An extension was carried out at $72^{\circ} \mathrm{C}$ for $5 \mathrm{~min}$. The quantitative qPCR amplified samples were analyzed by the BiONEER Exicycle ${ }^{\mathrm{TM}} 96$ (BioNEER, Daejeon, South Korea).

\section{Statistical analysis}

Differences with statistical significance were determined using one-way ANOVA test or KruskalWallis test, and Mann-Whitney U-test was used to compare differences between groups. $P$ values $<0.05$ were considered as statistically significant.

\section{Table 1: MAMLD1, AR, ER1, ER2, and GADPH primers}

\begin{tabular}{lll}
\hline Gen & Forward primer & Reverse primer \\
\hline MAMLD1 & TTTGCAACTCCAGCATCATC & CCTAACTCCTTCCCCTGGAC \\
AR & CCTGGCTTCCGCAACTTACAC & GGACTTGTGCATGCGGTACTCA \\
ER1 & ATTTCTCTGCGCCCCTAGAC & CATAGTGGTACCCAGACGCA \\
ER2 & TGAACTGGGCCCAGACTATG & ATGGTACCCTGAGGCGTAGT \\
GADPH & 5'-GCATCCTGGGCTACACTGAG-3' & 5'-TCCACCACCCTGTTGCTGTA-3' \\
\hline AR: Androgen, ER: Estrogen, MAMLD1: Mastermind-like domain 1.
\end{tabular}

\section{Results}

Periurethral dartos was harvested from 46 patients with proximal hypospadias, 24 patients with distal hypospadias during urethroplasty, and 10 patients with normal penile during circumcision as controls. Characteristic data of patients are presented in Table 2.

Table 2: Variable characteristics

\begin{tabular}{|c|c|}
\hline Variables & Value \\
\hline Age, year & $5(1-14)$ \\
\hline \multicolumn{2}{|l|}{ Hypospadias type, $n(\%)$} \\
\hline Distal & $24(30)$ \\
\hline Glandular & $5(6.3)$ \\
\hline Subcoronal & $2(2.5)$ \\
\hline Distal penile & $2(2.5)$ \\
\hline Midshaft & $14(17.5)$ \\
\hline Proximal penile & $1(1.3)$ \\
\hline Proximal & $46(57.5)$ \\
\hline Penoscrotal & $33(41.3)$ \\
\hline Scrotal & $12(15.0)$ \\
\hline Perineal & $1(1.3)$ \\
\hline Control & $10(12.5)$ \\
\hline MAMLD1, median (min-max) & $4.59(1.86-10.55)$ \\
\hline AR, Mean (SD)* & $6.84 \pm 2.57$ \\
\hline ER1, Median (min-max) & $14.92(4.59-39.39)$ \\
\hline ER2, Mean (SD) ${ }^{\star}$ & $21.89(8.14)$ \\
\hline \multicolumn{2}{|c|}{ Hypospadias characteristics penile torsion, $n(\%)$} \\
\hline Yes & $4(5.7)$ \\
\hline No & $66(94.3)$ \\
\hline \multicolumn{2}{|l|}{ Penile curvature, $\mathrm{n}(\%)$} \\
\hline Mild (<30 degrees) & $22(31.4)$ \\
\hline Moderate (30-60 degrees) & $14(20)$ \\
\hline Severe $(>60$ degrees $)$ & $34(48.6)$ \\
\hline \multicolumn{2}{|l|}{ Urethral plate, $\mathrm{n}(\%)$} \\
\hline Narrow $(<8 \mathrm{~mm})$ & $36(51.4)$ \\
\hline Wide $(\geq 8 \mathrm{~mm})$ & $34(48.6)$ \\
\hline \multicolumn{2}{|l|}{ Penoscrotal transposition } \\
\hline Yes & $9(12.9)$ \\
\hline No & $61(87.1)$ \\
\hline \multicolumn{2}{|l|}{ Bifid scrotum } \\
\hline Yes & $10(14.3)$ \\
\hline No & $60(85.7)$ \\
\hline \multicolumn{2}{|l|}{ Urethroplasty } \\
\hline First urethroplasty & $47(67.1)$ \\
\hline Redo-urethroplasty & $23(32.9)$ \\
\hline
\end{tabular}


The quantitative PCR analyses showed significantly decreased MAMLD1 expression in both distal $(5.33 \pm 2.21)$ and proximal $(4.82 \pm 2.42)$ hypospadias compared with the control group $(9.55 \pm 0.93)(p<0.05)$. Meanwhile, the expression of the AR showed decreases in both distal $(5.33 \pm 2.21)$ and proximal $(4.82 \pm 2.42)$ hypospadias compared to the control group (9.55 \pm 0.93 ) with significant difference $(p<0.05)$. In line with the result of MAMLD1 expression, ER1 showed decreasing

Table 3: Compared mean analysis among the groups

\begin{tabular}{lllll}
\hline Variable & Proximal hypospadias & Distal hypospadias & Control & $p$ \\
\hline MAMLD1 $^{\#}$ & $4.82( \pm 2.42)$ & $5.33( \pm 2.21)$ & $9.55( \pm 0.93)$ & $<0.001$ \\
AR $^{*}$ & $6.52( \pm 2.61)$ & $6.27( \pm 2.18)$ & $9.69( \pm 1.10)$ & $<0.001$ \\
ER1 $^{\#}$ & $15.31( \pm 6.49)$ & $17.93( \pm 8.22)$ & $12.82( \pm 2.23)$ & 0.158 \\
ER2* & $24.44( \pm 8.41)$ & $21.22( \pm 5.38)$ & $11.79( \pm 2.49)$ & $<0.001$ \\
\hline${ }^{"}$ Kruskal-Wallis, ${ }^{*}$ one-way ANOVA. AR: Androgen, ER: Estrogen, MAMLD1: Mastermind-like domain 1.
\end{tabular}

expression in both hypospadias types, with proximal $(15.31 \pm 6.49)$ and distal $(17.93 \pm 8.22)$ compared to the control group $(12.82 \pm 2.23)$. Reciprocally with ER1 and ER2 showed increasing expression in both hypospadias types, with proximal $(24.44 \pm 8.41)$ and distal $(21.22 \pm 5.38)$ compared to the control group (11.79 \pm 2.49$)$ (Table 3 and Figure 1).

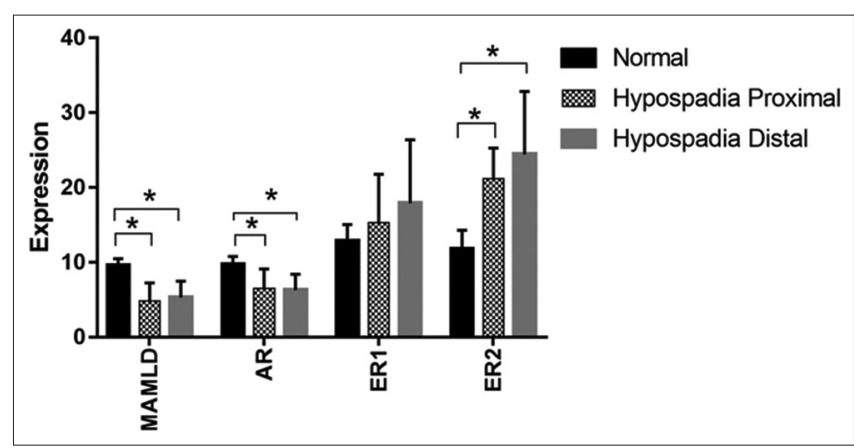

Figure 1: Expression of MAMLD1, androgen receptor, estrogen receptor 1, and estrogen receptor 2 in patients with hypospadias compared to the control group. AR: Androgen, ER: Estrogen, MAMLD1: Mastermind-like domain 1, *statistically significant

Post hoc analyses were used to explore which group was significantly related. It was revealed that there were significant differences in the MAMLD1, AR, and ER2 hypospadia groups (both distal and proximal) compared with the control group, while among hypospadias types, there were no significant differences (Table 4).

Table 4: Post hoc analysis

\begin{tabular}{|c|c|c|c|c|c|}
\hline \multirow[t]{2}{*}{ Variable dependent } & \multirow{2}{*}{\multicolumn{2}{|c|}{ Hypospadias type }} & \multirow[t]{2}{*}{$\mathrm{p}$} & \multicolumn{2}{|c|}{$95 \% \mathrm{Cl}$} \\
\hline & & & & Lower & Upper \\
\hline \multirow[t]{3}{*}{ MAMLD1 $^{\#}$} & Distal & Proximal & 0.199 & N/A & $\mathrm{N} / \mathrm{A}$ \\
\hline & Distal & Control & $<0.001$ & $\mathrm{~N} / \mathrm{A}$ & $\mathrm{N} / \mathrm{A}$ \\
\hline & Proximal & Control & $<0.001$ & N/A & $\mathrm{N} / \mathrm{A}$ \\
\hline \multirow[t]{3}{*}{$\mathrm{AR}^{*}$} & Distal & Proximal & 1.00 & -1.69 & 1.21 \\
\hline & Distal & Control & $<0.001$ & -5.59 & -1.26 \\
\hline & Proximal & Control & $<0.001$ & -5.19 & -1.17 \\
\hline \multirow[t]{3}{*}{ ER $1^{\#}$} & Distal & Proximal & 0.195 & N/A & $\mathrm{N} / \mathrm{A}$ \\
\hline & Distal & Control & 0.059 & $\mathrm{~N} / \mathrm{A}$ & $\mathrm{N} / \mathrm{A}$ \\
\hline & Proximal & Control & 0.121 & $\mathrm{~N} / \mathrm{A}$ & $\mathrm{N} / \mathrm{A}$ \\
\hline \multirow[t]{3}{*}{$\mathrm{ER}^{*}$} & Distal & Proximal & 0.230 & -7.60 & 1.17 \\
\hline & Distal & Control & 0.002 & 2.87 & 15.98 \\
\hline & Proximal & Control & $<0.001$ & 6.56 & 18.72 \\
\hline
\end{tabular}
like domain 1 .

Linear regression analysis of each of the mRNA expressions showed the AR expression and MAMLD1 expression had strong correlation $(r=0.062)$ and the positive pattern indicates that the more MAMLD1 expression is reduced, the AR expression will also decrease. Furthermore, the post hoc results showed a significant association between AR expression and MAMLD1 expression with $p=0.038$ (Table 5).

\section{Discussion}

The etiology of hypospadias cases, however, is not yet solved. Genes or environmental factors may play a principal role in the pathogenesis of hypospadias. Hypospadias can be equally transmitted through the maternal and paternal sides of the family and recurrence risks for brothers and sons of hypospadias cases are similar [12]. Various genes are known to be implicated in testes development, masculinization, and hypospadias such as MAMLD1, AR, ER1, and ER2. Mutations that affect the ability of the gonads to produce these hormones or the cell's sensitivity to these hormones can result in anomalies of male development including hypospadias [6].

MAMLD1 (previously known as CXorf6) located on human chromosome $\mathrm{Xq28}$ is a causative gene for hypospadias, a mild form of 46, XY DSD [13]. At present, multiple mutations have been reported in patients with various types of hypospadias [13], [14], [15]. In this regard, the mouse homologous gene MAMLD1 is transiently expressed in fetal Sertoli and Leydig cells around the critical period for sex development [13], and transient MAMLD1 knockdown using small interfering RNAs (siRNAs) reduces testosterone production in cultured mouse Leydig tumor cells (MLTCs) [13]. Various mutations affect the expressions of MAMLD1 in patients with hypospadias. They were downregulated compared to the control group. These findings are similar with other studies which stated that the mRNA level of MAMLD1 was severely reduced (25-30\%) in the MLTCs with reduction in testosterone production (50-60\%) [8]. This association between testosterone production and expression of MAMLD1 is consistent with the hypospadias phenotype in the affected patients [16].

ARs affect and play an important role in the prenatal and postnatal development of the urogenital tract, especially the penis [17]. The present study showed a decrease in the expression of the AR in patients with hypospadias compared to the control group. Decreased AR expression may be affected by elevation in the number of CAG repeats. The relationship between CAG repeats and AR transcriptional activity has not been well explored. The AR gene is composed of eight exons and is located on the $\mathrm{X}$ chromosome at q11-q12. Exon 1 of the AR gene contains a polymorphic sequence of CAG repeats, which usually varies in number from 10 to 35, which encodes polyglutamine stretches of AR transactivation domain [18], [19]. Many findings suggest that the CAG number is negatively correlated with AR transcriptional activity [20]. In fact, patients affected by Kennedy 
Table 5: Linear regression analysis between MAMLD1 and AR, ER1, and ER2 in hypospadias group

\begin{tabular}{|c|c|c|c|c|c|c|c|c|c|}
\hline \multirow[t]{2}{*}{ Model } & & \multicolumn{2}{|c|}{ Unstandardized coefficients } & \multirow{2}{*}{$\begin{array}{l}\text { Standardized coefficients } \\
\text { Beta }\end{array}$} & \multirow[t]{2}{*}{$\mathrm{r}$} & \multirow[t]{2}{*}{$\mathrm{t}$} & \multirow[t]{2}{*}{$\mathrm{p}$} & \multicolumn{2}{|c|}{$95 \%$ confidence interval for B } \\
\hline & & B & SE & & & & & Lower bound & Upper bound \\
\hline \multirow[t]{2}{*}{ AR } & (Constant) & 5.129 & 0.678 & & & 7.567 & 0.000 & 3.776 & 6.481 \\
\hline & MAMLD1 & 0.261 & 0.123 & 0.249 & 0.062 & 2.120 & 0.038 & .015 & 0.506 \\
\hline \multirow[t]{2}{*}{ ER1 } & (Constant) & 17.990 & 2.029 & & & 8.867 & 0.000 & 13.942 & 22.039 \\
\hline & MAMLD1 & -0.357 & 0.368 & -0.117 & 0.014 & -0.971 & 0.335 & -1.092 & 0.377 \\
\hline \multirow[t]{2}{*}{ ER2 } & (Constant) & 26.075 & 2.137 & & & 12.199 & 0.000 & 21.810 & 30.340 \\
\hline & MAMLD1 & -0.548 & 0.388 & -0.169 & 0.029 & -1.415 & 0.162 & -1.322 & 0.225 \\
\hline
\end{tabular}

AR: Androgen, ER: Estrogen, MAMLD1: Mastermind-like domain 1, SD: Standard deviation.

syndrome have a number of CAG repeats $>40$ together with decreased virilization, reduced sperm production, testicular atrophy, and infertility [18]. Repeat length is positively affecting AR transcriptional activity in skeletal muscle, while the opposite appears in prostate cells. It is possible that alterations of the repeat length induce conformational changes in the AR N-terminal domain that enhance or suppress transcriptional cofactor and AR-associated protein interactions [21]. Other studies have shown that ethnic differences in CAG repeat length of the AR gene exist between African, Caucasian, and Asian populations. The allele expansion found in Africans is between 18 and 20 repeats, although some African subpopulations seem to have a shorter track [22]. In contrast, Caucasian and Asian populations have a longer expansion, where the mean number of CAG repeats is $21-22$ in Caucasians [20] and 23 in Asians [23].

This research also found a positive correlation between MAMLD1 and AR. The result of our study showed a decreased in expression MAMLD1 similar to the expression AR which has decreased. It is known that defects in the AR function and its regulatory mechanisms contribute to the development of hypospadias [24].

Several studies showed that the expressions of ER and AR can also influence the development of male external genitalia [11], [25], [26], [27], [28]. Our study found that both ERs, including ER1 and ER2, have elevated expression compared to the control group. These findings show a counterbalance between $A R$ and ER. Dominant expression of ER receptors in the penile tissues of children with hypospadias and the theory of disrupted AR and ER receptors interaction and/or balance could play a role during the development of external genitalia in patients with hypospadias [17]. Reduced testosterone levels and elevated ER levels may also be a risk factor for hypospadias [6], [29]. Interestingly, there were no studies that definitively stated that endocrine disruptors caused hypospadias. However, there were multiple studies that implicated endocrine disruptors as one component of a multifactorial model for hypospadias.

One limitation of this study is the nature of the cross-sectional study that does not include following the possibility of changes of the expression ER2 overtime. However, as far as we know, this is the first study that discussed about ER2 and its role in hypospadias in an Asian population.

\section{Conclusions}

Decreasing MAMLD1 and AR expressions were followed by increasing ER2 expression in hypospadias patients. MAMLD1 had a positive correlation with AR so the defect of MAMLD1 may influence AR and increase the incidence of hypospadias.

\section{Ethics Approval and Consent to Participate}

The Ethical Committee of Faculty of Medicine, Universitas Gadjah Mada/Dr. Sardjito Hospital gave approval for this study (KE/1049/09). Written informed consent was obtained from all parents for participating this study.

\section{Acknowledgment}

We thank all staff and nurses who took care of the patients.

\section{References}

1. Kurahashi N, Sata F, Kasai S, Shibata T, Moriya K, Yamada H, et al. Maternal genetic polymorphisms in CYP1A1, GSTM1 and GSTT1 and the risk of hypospadias. Mol Hum Reprod. 2005;11(2):93-8. https://doi.org/10.1093/molehr/gah134 PMid:15579657

2. Snodgrass W, Macedo A, Hoebeke P, Mouriquand PD. Hypospadias dilemmas: A round table. J Pediatr Urol 2011;7(2):145-57. https://doi.org/10.1016/j.jpurol.2010.11.009 PMid:21236734

3. Leung AK, Robson WL. Hypospadias: An update. Asian J Androl. 2007;9(1):16-22. PMid:17187155

4. AlbertN, Ulrichs C, GluerS, HiortO, SinneckerGH, MildenbergerH, et al. Etiologic classification of severe hypospadias: Implications for prognosis and management. J Pediatr. 1997;131(3):386-92. https://doi.org/10.1097/00005392-199804000-00115 


\section{PMid:9329414}

5. Willingham E, Baskin LS. Candidate genes and their response to environmental agents in the etiology of hypospadias. Nat Clin Pract Urol. 2007;4(5):270-9. https://doi.org/10.1038/ncpuro0783 PMid: 17483812

6. Bouty A, Ayers KL, Pask A, Heloury Y, Sinclair AH. The genetic and environmental factors underlying hypospadias. Sex Dev. 2015;9(5):239-259. https://doi.org/10.1159/000441988 PMid:26613581

7. Miyado M, Nakamura M, Miyado K, Morohashi KI, Sano S, Nagata $\mathrm{E}$, et al. Mamld1 deficiency significantly reduces mRNA expression levels of multiple genes expressed in mouse fetal leydig cells but permits normal genital and reproductive development. Endocrinology. 2012;153(12):6033-40. https:// doi.org/10.1210/en.2012-1324

PMid:23087174

8. Ogata T, Wada Y, Fukami M. MAMLD1 (CXorf6): A new gene for hypospadias. Sex Dev. 2008;2(4-5):244-50. https://doi. org/10.1159/000152040

PMid:18987498

9. Van Der Zanden LF, Van Rooij IA, Feitz WF, Franke B, Knoers NV, Roeleveld N. Aetiology of hypospadias: A systematic review of genes and environment. Hum Reprod Update. 2012;18(3):26083. https://doi.org/10.1093/humupd/dms002

PMid:22371315

10. Bouchoucha N, Samara-Boustani D, Pandey AV, BonyTrifunovic H, Hofer G, Aigrain Y, et al. Characterization of a novel CYP19A1 (aromatase) R192H mutation causing virilization of a $46, X X$ newborn, undervirilization of the $46, X Y$ brother, but no virilization of the mother during pregnancies. Mol Cell Endocrinol. 2014;390(1-2):8-17. https://doi.org/10.1016/j.mce.2014.03.008 PMid:24705274

11. Dietrich W, Haitel A, Huber JC, Reiter WJ. Expression of estrogen receptors in human corpus cavernosum and male urethra. J Histochem Cytochem. 2004;52(3):355-60. https://doi. org/10.1177/002215540405200306

PMid:14966202

12. Schnack TH, Zdravkovic S, Myrup C, Westergaard T, Christensen $\mathrm{K}$, Wohlfahrt $\mathrm{J}$, et al. Familial aggregation of hypospadias: Acohort study. Am J Epidemiol. 2008;167(3):251-6. https://doi.org/10.1093/aje/kwm317

PMid:18042671

13. Fukami M, Wada Y, Miyabayashi K, Nishino I, Hasegawa T, Camerino $\mathrm{G}$, et al. CXorf6 is a causative gene for hypospadias. Nat Genet. 2006;38(12):1369-71. https://doi.org/10.1038/ ng1900

PMid:17086185

14. Kalfa N, Liu B, Klein O, Audran F, Wang MH, Mei C, et al. Mutations of CXorf6 are associated with a range of severities of hypospadias. Eur J Endocrinol. 2008;159(4):453-8. https://doi. org/10.1530/eje-08-0085 PMid: 18635673

15. Chen $\mathrm{Y}$, Thai HT, Lundin J, Lagerstedt-Robinson $\mathrm{K}$, Zhao $\mathrm{S}$, Markljung $\mathrm{E}$, et al. Mutational study of the MAMLD1-gene in hypospadias. Eur J Med Genet. 2010;53(3):122-6. https://doi. org/10.1016/j.ejmg.2010.03.005 PMid:20347055

16. Achermann JC, Hughes I. Pediatric disorders of sex development. In: Williams Textbook of Endocrinology. Philadelphia, PA: Elsevier; 2016.

17. Celayir A. Expression of androgen, estrogen, and progesterone hormone receptors in the penile tissues of children with different types of hypospadias. North Clin Istanb. 2018;6(2):110-6. https://doi.org/10.14744/nci.2018.47108
PMid:31297475

18. Tirabassi G, Muti ND, Corona G, Maggi M, Balercia G. Androgen receptor gene CAG repeat polymorphism regulates the metabolic effects of testosterone replacement therapy in male postsurgical hypogonadotropic hypogonadism. Int J Endocrinol. 2013;2013:816740. https://doi.org/10.1155/2013/816740 PMid:24454369

19. Francomano D, Greco EA, Lenzi A, Aversa A. CAG repeat testing of androgen receptor polymorphism: Is this necessary for the best clinical management of hypogonadism? J Sex Med. 2013;10(10):2373-81. https://doi.org/10.1111/jsm.12268 PMid:23844628

20. Ferlin A, Bartoloni L, Rizzo G, Roverato A, Garolla A, Foresta C. Androgen receptor gene CAG and GGC repeat lengths in idiopathic male infertility. Mol Hum Reprod. 2004;10(6):417-21. https://doi.org/10.1093/molehr/gah054

PMid: 15044606

21. Sheppard RL, Spangenburg EE, Chin ER, Roth SM. Androgen receptor polyglutamine repeat length affects receptor activity and $\mathrm{C} 2 \mathrm{C} 12$ cell development. Physiol Genomics. 2011;43(20):1135-43. https://doi.org/10.1152/ physiolgenomics.00049.2011

PMid:21828246

22. Zitzmann M, Nieschlag E. The CAG repeat polymorphism within the androgen receptor gene and maleness. Int J Androl. 2003;26(2):76-83. https://doi. org/10.1046/j.1365-2605.2003.00393.x

PMid: 12641825

23. Tse JY, Liu VW, Yeung WS, Lau EY, Ng EH, Ho PC. Molecular analysis of the androgen receptor gene in Hong Kong Chinese infertile men. J Assist Reprod Genet. 2003;20(6):227-33.

PMid: 12877254

24. Vottero A, Minari R, Viani I, Tassi F, Bonatti F, Neri TM, et al. Evidence for epigenetic abnormalities of the androgen receptor gene in foreskin from children with hypospadias. J Clin Endocrinol Metab. 2011;96(12):E1953-62. https://doi. org/10.1210/jc.2011-0511

PMid:21937623

25. Crescioli C, Maggi M, Vannelli GB, Ferruzzi P, Granchi S, Mancina $\mathrm{R}$, et al. Expression of functional estrogen receptors in human fetal male external genitalia. J Clin Endocrinol Metab. 2003;88(4):1815-24. https://doi.org/10.1210/jc.2002-021085 PMid:12679479

26. Kim KS, Liu W, Cunha GR, Russell DW, Huang H, Shapiro E, et al. Expression of the androgen receptor and 5 alpha-reductase Type 2 in the developing human fetal penis and urethra. Cell Tissue Res. 2002;307(2):145-53. https://doi.org/10.1007/ s004410100464

PMid: 11845321

27. Mowa CN, Jesmin S, Miyauchi T. The penis: A new target and source of estrogen in male reproduction. Histol Histopathol. 2006;21(1):53-67.

PMid: 16267787

28. Schultheiss D, Badalyan R, Pilatz A, Gabouev Al, Schlote N, Wefer $\mathrm{J}$, et al. Androgen and estrogen receptors in the human corpus cavernosum penis: Immunohistochemical and cell culture results. World J Urol. 2003;21(5):320-4. https://doi. org/10.1007/s00345-003-0371-y PMid: 14586547

29. Staib P, Kau N, Romalo G, Schweikert HU. Oestrogen formation in genital and non-genital skin fibroblasts cultured from patients with hypospadias. Clin Endocrinol (Oxf). 1994;41(2):237-43. https://doi.org/10.1111/j.1365-2265.1994.tb02536.x PMid:7923829 